\title{
Evoking Timelessness through Integration between Old and New Building
}

\author{
Mohammad Irfan Andhikaputra and V. Totok Noerwasito \\ Departemen Arsitektur, Fakultas Teknik Sipil dan Perencanaan, Institut Teknologi Sepuluh Nopember (ITS) \\ e-mail: vtonoer@arch.its.ac.id
}

\begin{abstract}
Architecture is inevitably influenced by time. One of the possible way to witness the influence of time in architecture is looking through the present old-structure building. The building that holds historical value to its society, are able to be used over time while retaining its form but adaptively reused by society to fulfill their needs. In the other hand, some buildings are just left abandoned by its society, although it may have the same value with the other "timeless" building. As to retain its historical identity, the government has issued some projects to rejuvenate this sector of Kota Tua. Selected site is developed and adapted, given its newest function as a museum by using pattern language and adaptive reuse as a method to achieve a suitable look of a timeless concept. The implementation of Timelessness into selected site is the main idea of this project, by placing the new structure adaptively through existing building, the integration of the old and new structure is achieved.
\end{abstract}

Keywords-Accessibility, Museum, Perception, Pattern Language, Sustainability, Timeless.

\section{INTRODUCTION}

A RCHITECTURE in its physical form, or materialized form, exist by a process of translation. The process of translating a drawing into a built object surely influenced by several aspects. This is referring to some aspects that interfere with the process of materializing the building, such as construction, environment, budgets, and the exact aspect of all, time. Time in architecture has always got a role to influence architecture [1].

Time would always exist in the process of translating architecture, far from the very beginning project until the building was built completely, and even after the building is built. The influence of time in architecture that is easily seen is in the life of a building. Architecture has widely known to represent its era; this notion came up by the facts that we can easily know the era of its built by looking at the building [2]. We can roughly know that the building is built in the colonial era, the modern era, and so on. The district of Kota Tua has been the root of Jakarta city development on the colonial era in Indonesia. Starting in the $17^{\text {th }}$ century, to the early of $20^{\text {th }}$ century, the district of Kota Tua has been central to governance, politics, commercial functions, and trading area [3].

The development of the port city of Batavia (former name for Jakarta) has made Kota Tua become the icon of historical identity of Jakarta. After the Independence Day of Indonesia, Soekarno, the first president of the country, has planned to develop the city with a linear axis, hoping Jakarta will grow much larger than the existing centralized axis. As the result, Monumen Nasional or widely known as Monas becomes a new magnet of civilization. The main street of Sudirman Thamrin, has made Kota Tua gradually fade and abandoned. Some of the building, especially the "important" building is still being used until today. The Fatahillah Museum was formerly used as a city hall in the $18^{\text {th }}$ century with its own historical identity, and value and the building holds has made the building to be continually used until today. Although some of the old building is still being used, many of them are being abandoned and left. In fact, some of its owners are just left the building to decay [3].

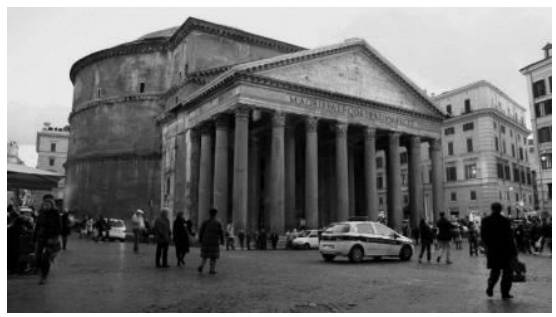

Figure 1. Rome's Mausoleum of Hadrian [4] (Gizmodo).

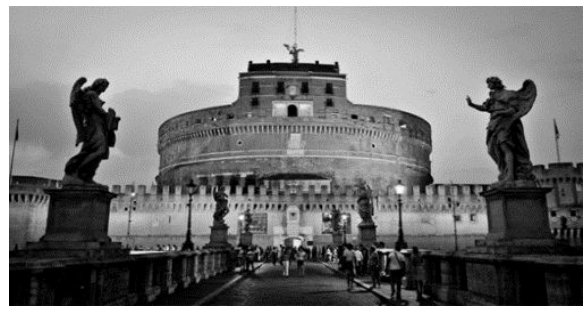

Figure 2. The Pantheon in Rome [4].

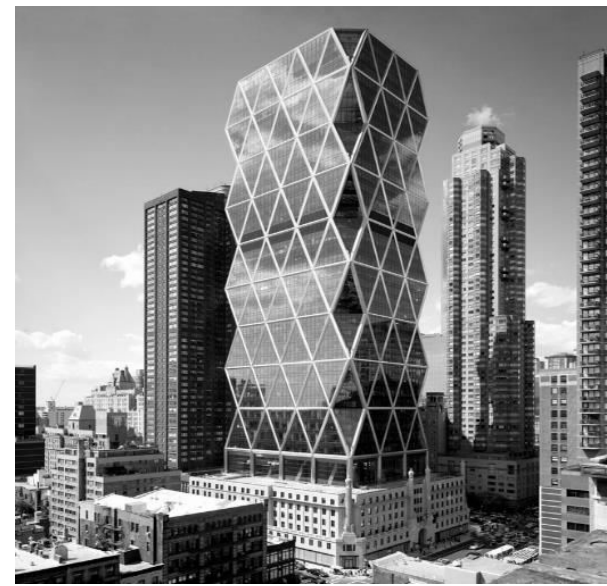

Figure 3. The Hearst Tower [2]. 


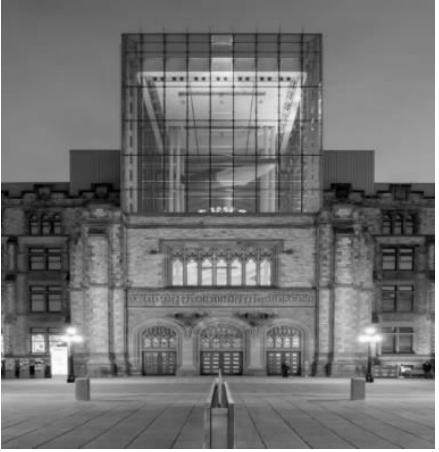

Figure 4. Canadian Museum of Nature [2].

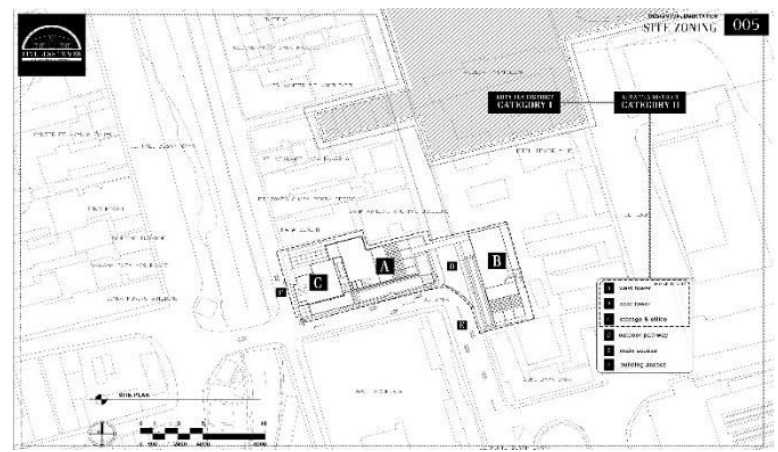

Figure 5. Building Siteplan.

As to evoke the historical identity, the main framework is to obey the basic pattern language of building, to achieve the "timelessness" of a building. The pattern language codifies the interaction of human beings with their environment and determines how and where we naturally prefer to walk, sit, sleep, enter and move through a building, enjoy a room or open space, and feel at ease or not in our garden [5]. The pattern language is a set of inherited tried-and-true solutions that optimize how the built environment promotes human life and sense of well-being. It combines geometry and social behavior patterns into a set of useful relationships, summarizing how built form can accommodate human activities [6].

\section{DESIGN METHODS}

\section{A. Adaptive Reuse}

According to the book "the nine lives of building", Adaptive Reuse, As the name suggests, is all about use. While the cultural significance of the building's original purpose may be evident in its structure, sitting or ornament, very often the old site or building is redesigned to meet a purpose other than the one for which it was first intended. Perhaps the most pragmatic of a building's many possible lives, it is a strategy that can be repeated again and again to the same structure. As with renovation, preservation and restoration advocates may challenge adaptive reuse proposals [7]. By itself, adaptive reuse is most often economically motivated, unsentimental and without nostalgia [8].

\section{B. A Pattern Language - The Timeless Way of a Building}

In the book the timeless way of a building, it is shown there that towns and buildings will not be able to become alive, unless they are made by all the people in society, and unless
Table. 1.

Formal Application Criteria

\begin{tabular}{ll}
\hline \hline \multicolumn{1}{c}{ Application criteria } & Application in building \\
\hline $\begin{array}{l}\text { Should be able to sustain } \\
\text { the technicality of the } \\
\text { building }\end{array}$ & $\begin{array}{l}\text { Low Maintenance } \\
\text { Factors }\end{array}$ \\
$\begin{array}{l}\text { Should be able to define the } \\
\text { building as a low- } \\
\text { maintenance Building }\end{array}$ & Accessibility Concept \\
$\begin{array}{l}\text { Should be able to increase } \\
\text { the accessibility of the } \\
\text { building }\end{array}$ \\
\hline \hline
\end{tabular}

Table. 2.

Technical Application Criteria

\begin{tabular}{ll}
\hline \hline \multicolumn{1}{c}{ Application criteria } & Application in building \\
\hline $\begin{array}{l}\text { Should be able to give a } \\
\text { timeless perception through } \\
\text { the user by form and spatial } \\
\text { experience in the building. }\end{array}$ & $\begin{array}{l}\text { Room Form } \\
\text { Fattern Circulation, } \\
\text { Pattern Visual, } \\
\text { Pattern Ambience, }\end{array}$ \\
$\begin{array}{l}\text { Should be able to provide a } \\
\text { visual, color, ambiance, } \\
\text { landscape requirement } \\
\text { through the building }\end{array}$ & $\begin{array}{l}\text { Poom Colors } \\
\text { Pattern Building Form }\end{array}$ \\
Retaining Façade
\end{tabular}

these people share a common pattern language, within which to make these buildings, and unless this common pattern language is alive itself. To understand the pattern and its connection to the building itself, the chosen pattern is derived from human (user) eyesight in rooms that causes an impression [9].

In this method, the collection of art is also considered to be one of the main key function of the building. The perception of timelessness through the society is achieved through this method, by the previous methods 'adaptive reuse', which focused on the function of the whole projects, the pattern language method is a term used for manipulating perception of time for the user, as it is one of the concern to create a memory and perception throughout the society or the user of the building [10].

\section{DESIGN CONCEPTS AND RESULTS}

The timeless tower main concept is to create timelessness according to the context of the site and built environment. To create timelessness, several concepts that are previously explained in design criteria are used to create a specifics design concept. The main criteria of the concept are to add value to existing building that is achieved by several specific concepts. The value which would be added is a value of historical memories that embedded through the district of Kota Tua.

The formal exploration includes implementation of the pattern language, such as room form, spatial experience, visual, ambiance and colors. The understanding of each pattern is applied through the building by each of the buildings. 

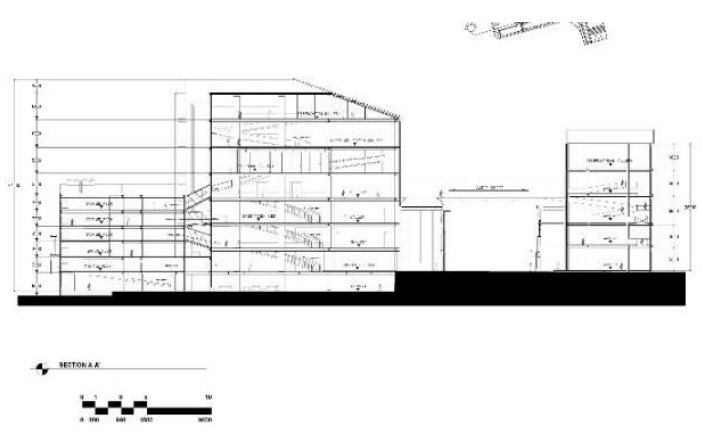

Figure 6. Building Section.
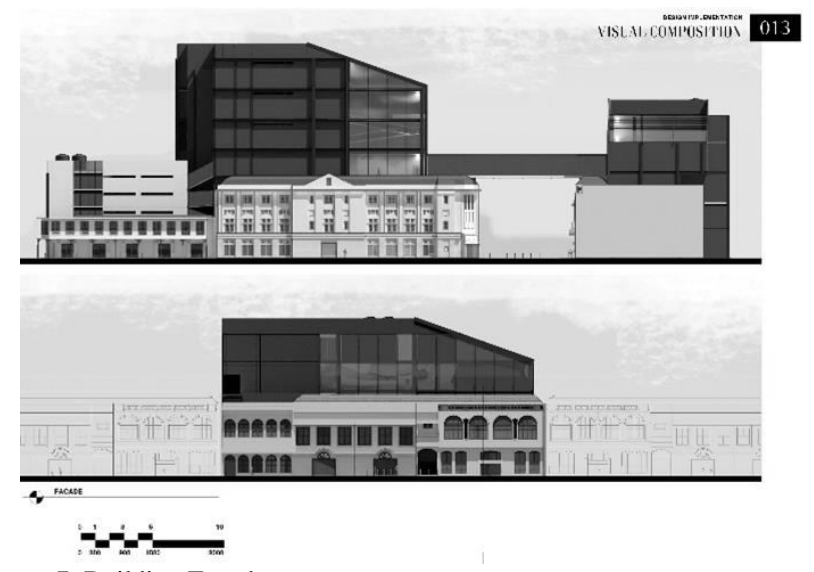

Figure 7. Building Façade.
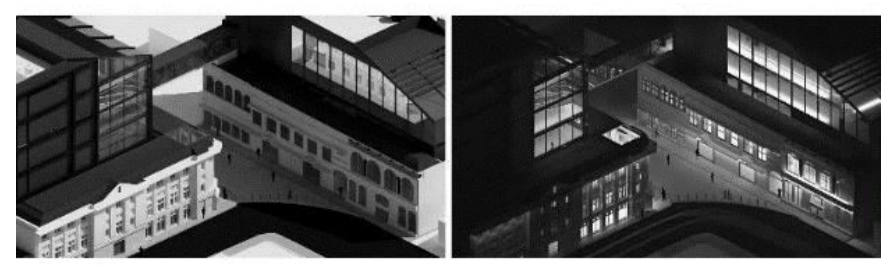

Figure 8. Day and Night Perspective.

There are two main categories of the pattern language, first, is the creation of the building complex and the overall building mass. Second, is the creation of the building elements and room configuration

The interpretation of the pattern above is to spread the building function on both sites. The separated mass of the building made the building able to serve and used by a large number of users at the same time. With its larger possible entrances, the museum should able give a timelessness perception of the citizen itself.

The main function of the building as a museum is represented by the main mass that is higher to the surrounding mass. This is also to state that the whole building complex is focused on its center. The appearance of the tower has also intended to emphasize the main function of the adapted site. The smaller mass is functioned as office and storage.

The entrance of this museum is spread into several locations. This enables the building to be used collectively by its user and exists as the existing building - which has its own entrance to the building. The separated entrance has also made the observation throughout the museum become timeless, this is proven by the user interaction over the building. The entrance to the building also react as the main access to the

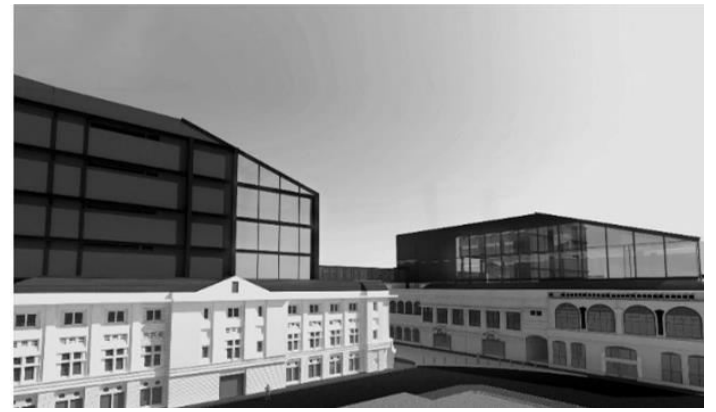

Figure 9. Aerial View.
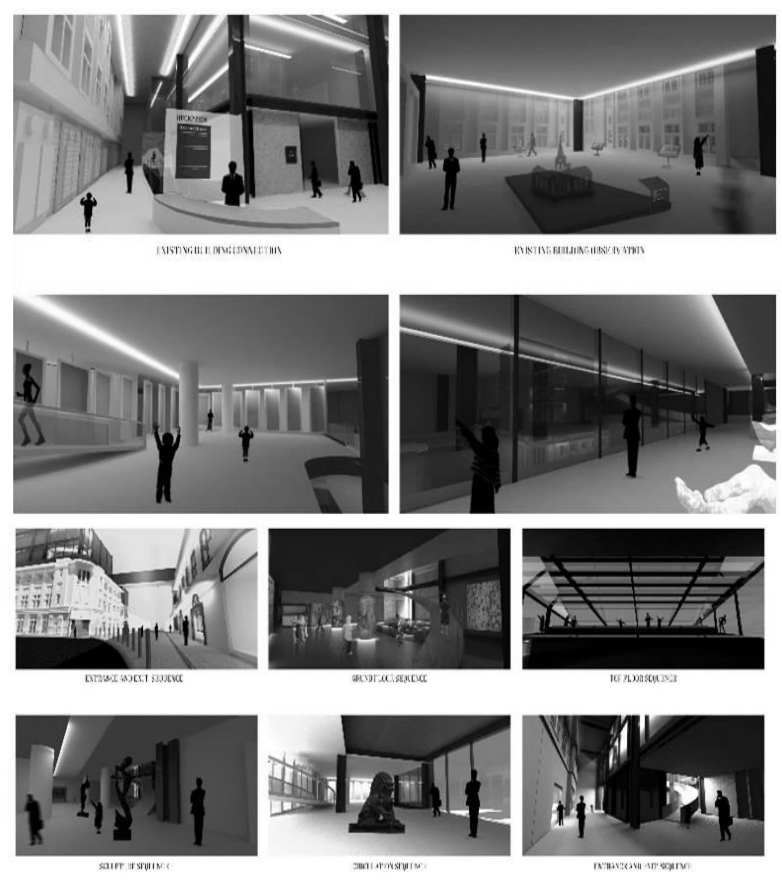

Figure 10. Interior Perspective.

building, this is also related to intensifying the accessibility and maintainability of the building.

Technical aspect also the main concern of a sustainable museum. The main idea of the concept is to enable the building to survive and to be properly usable in the future phrase. The main application criteria are done by reducing the maintenance factors over the building, and to increase the accessibility over the building. The main key to sustaining the museum is to provide a supporting mass which function as office and storage. This direct massing concept is also allowing the building to be easily maintained and the collection to be added or preserved.

The technical exploration is also consisted of building utility integrity, which consisted of Structural System, HVAC System, Electrical, Transportation, Plumbing, Fire Protection, and CCTV System.

\section{CONCLUSION}

The main framework is to rejuvenate the historical identity of Kota Tua Jakarta. This project is placed as an initial building to start the whole process to retaining the historical identity in Kota Tua. Adaptive reuse methods and following 
the pattern language to achieve specific condition of the museum itself. The integration of the new structure affects the old structure to be rejuvenated afterwards. The expansion of the new structure also creates a new space and feel throughout the old structure. Otherwise, the impression of the new structure creates a new feel as the main intention to rejuvenate the historical identity of Kota Tua itself. The new structure is connected by a bridge as a impression of integrated area, which is also the creates integration between the old and new structure.

\section{REFERENCES}

[1] K. Lynch, What Time Is This Place? Massachusets: MIT Press, 1972.

[2] E. Allen, "Norman Foster, Daniel Libeskind, and More Breathe New Life Into 10 Old Structures," 2016. [Online]. Available: http://www.architecturaldigest.com/gallery/adaptive-reuse-modernarchitecture/all.

[3] Y. Antar, "Yori Antar: "Menghidupkan Kota Mati," V. Magazine, Jan2016.

[4] A. Nagy, "17 of the oldest man-made structure on earth still in use," 2013. .

[5] J. Stoner, "The Nine Lives of Building. In K. A. Frank, Architecture Timed: Designing With Time in Mind," 2016.

[6] J. Pallasmaa, "Inhabiting Time. In K. A. Frank, Architecture Timed: Designing With Time In Mind," 2016.

[7] M. Joachim, "Adaptive Reuse. Massachusetts: Massachusetts Institute of Technology," 2011. .

[8] D. Fisher-Gewirtzman, "Adaptive Reuse Architecture Documentation and Analysis," J. Archit. Eng. Technol., 2016.

[9] C. Alexander, The Timeless Way of Building. New York: Oxford University Press, 1979.

[10]Z. W. Paszkowski, Timeless Values in Architecture. Biblioteka Cyfrowa Politechniki Krakowskiej. 